\title{
無人小型視察ロボットの開発*
}

\author{
妻木 俊道*1, 内田 康之*2，福島 $\mathrm{E}$. 文彦*3, 三浦 有信*4, 玉田 守*5
}

\section{Development of the Unmanned Small Scout Robot}

\author{
Toshimichi TSUMAKI*1 ${ }^{1}$, Yasuyuki UCHIDA, Edwardo F. FUKUSHIMA, \\ Yushin MIURA and Mamoru TAMADA \\ ${ }^{* 1}$ Mitsubishi Heavy Industries, ltd. Sagamihara \\ 3000 Tana, Chuuo-ku, Sagamihara city, Kanagawa, 252-5293 Japan
}

We introduce the wireless remote controlled unmanned small scout robot. The robot is aimed to scout and work in dangerous area for example the area of the crime or the terrorism and in the poisonous gas atmosphere. It can move around mainly artificial place like in the building with many stairs and can be operated by wireless system from out-of-sight area. And it can be carried to anywhere by one man's shouldering. The robot can start from the base floor to other floor by stairs inclination up to 40 degrees, and scouts with multi camera system and works with a manipulator around the troubled area. After the mission, it returns to the start point on the base floor. All operation and monitoring can be held at the start point. We report that we tested and evaluated the operation and some semiautomatic assist systems for driving about the robot.

Key Words : Robot, Scout Robot, EOD, Unmanned, Remote Control, Multi Crawler, Dangerous, Stairs

\section{1. は じめに}

危険な状況（事件，テロなど），危険な䨌囲気（ガス，放射線など）にある現場に，人が入って対応をすると， 二次災害を招き，返って事を大きくする場合がある。それら危険現場には，無人ロボットを投入して，視察，そ して作業を行うことで，人にはできない積極的な活動が可能となる(1). 近年，それら目的のロボットが開発されて いるが，海外では特に原子力，軍事用途の実績(2)が多い. 安全と言われたわが国でもそのような器材の必要性は高 まっている，そうしたロボットの運用性を検証するため，試作，試験，評価を行ったので報告する.

\section{2. コンセプト}

1 章で述べたような状況で, ロボットに求められる要目をまとめると以下のようになる.

(1)市街，階段のある建物内を自由に移動できる.

（2）小型・軽量で現場付近に容易かつ速やかに搬入できる.

（3）ロボット自体を見えない場所から遠隔操縦できる.

(4) 遠隔操縦は操作性がよく，半自動化等のアシストがある.

(5)サンプル収集等の作業が可能なマニピュレータを備える.

(6)遠隔操縦以外の, 動力部, 走行制御部は自立式である.

* 原稿受付 2012 年 5 月 6 日

*1 正員，三菱重工業 (株)（广252-5293 神奈川県相模原市中央区田名 3000）

${ }^{* 2}$ 正員, 日本大学 生産工学部

*3 正員, 東京工業大学大学院 機械宇宙システム専攻

*4 (株) ヤマテコーポレーション

*5 (有)イーストドライブ

E-mail: toshimichi_tsumaki@mhi.co.jp 


\section{3. 仕 様}

2 章の要目から,さらに具体的な仕様をまとめた.

（1）一般の建物では，建築基準法などから，その階段の最大傾斜角は約 $35 \mathrm{deg}$ となっている．従って，35deg 以上の傾斜を登降坂できる必要がある. そのために, 左右にクローラを有する装軌式とし, クローラは階段 のエッジに引掛かるラグを付けたものとした。また，登降坂角を高めるため重心を下げる必要があり，車高 を低くした。クローラ高さが低くなるので，登坂時は階段のエッジにクローラが引掛かるようにするため， 図 1 のように車体前端に起倒可動式のサブクローラ（フリッパ）を設け，乗り上げができるようにした.

また，図 2 のように，階段から踊り場に乗り上がる際，車体重心が踊り場手前エッジを越えると，車体は 一気に前に倒れ込む. その際, ロボットには衝撃が加わり, 安定上, 良くない. また, 踊り場から階段に降 りる際も同様である. それら挙動を改善するため，上記の起倒可動式のサブクローラ（フリッパ）式構造， あるいはマルチクローラ式構造が有効であると考えた.

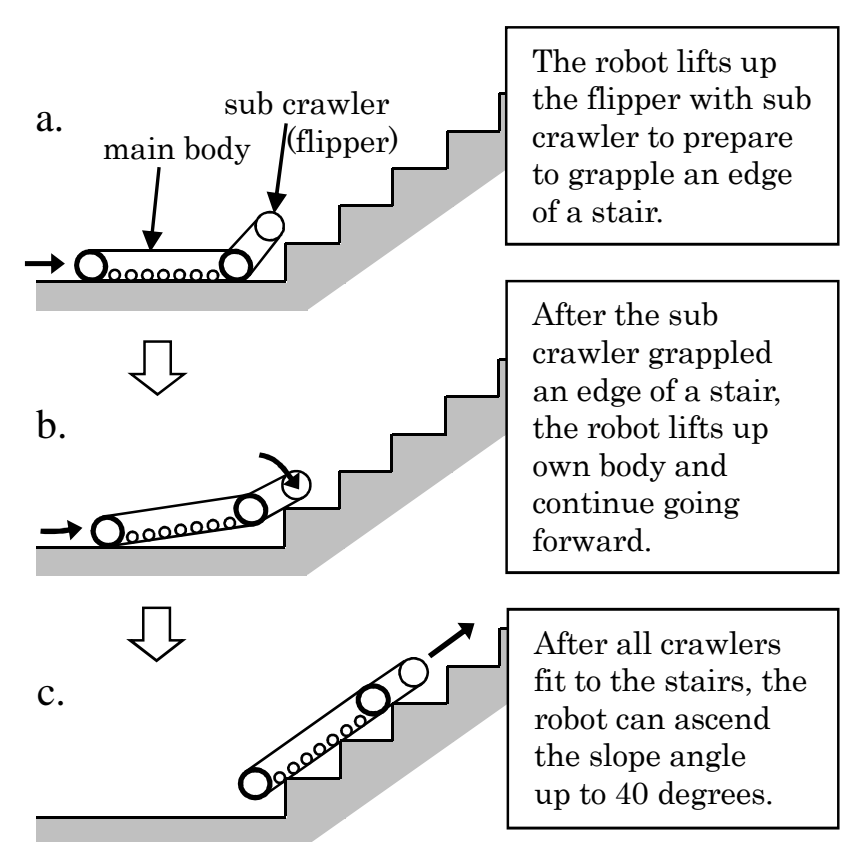

Fig.1 The sequence of ascending the stairs

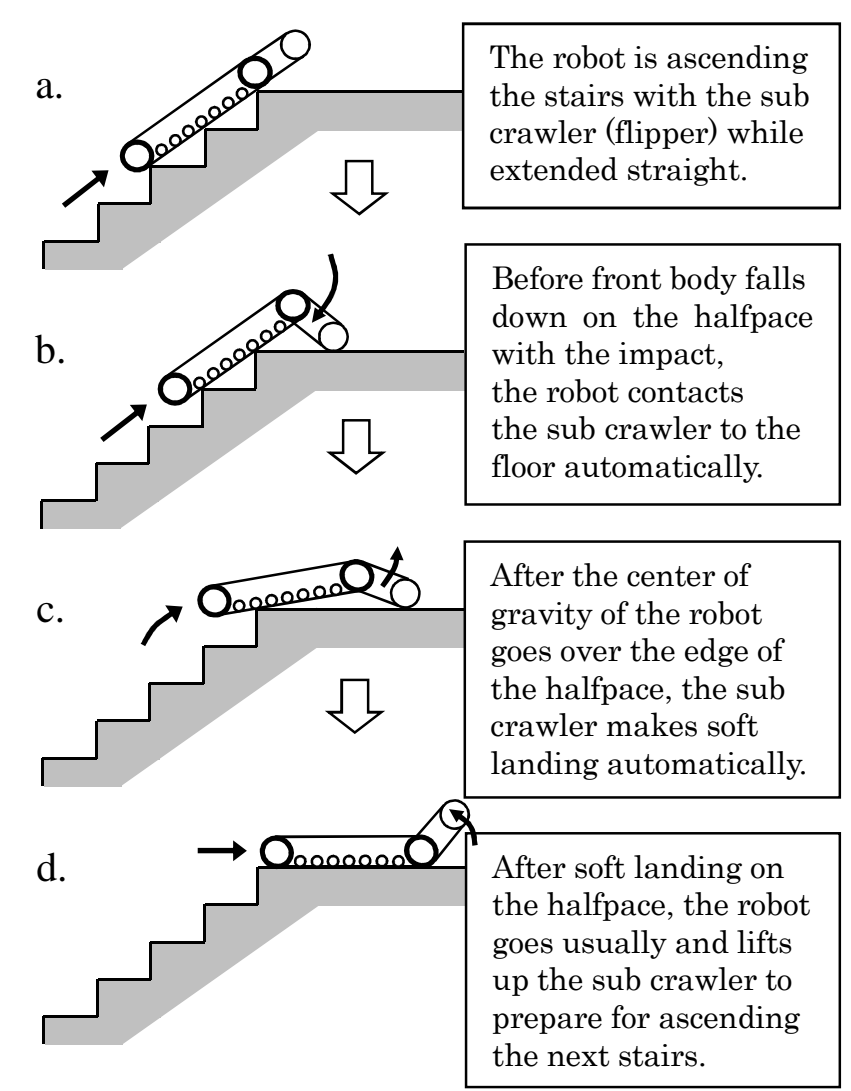

Fig.2 The sequence of getting on the landing softly

米国 iRobot 社の'Packbot'(3)は，単純な構造の前方のみの左右独立サブクローラ（フリッパ）を備え，屋外 自然地形での走破性を有し，主に軍用で普及した。'ROBHAZ-DT3' (4)は車体を階段に適応しやすい形状のフ ロントトラックと, フラット形状のリアトラックとに分割し，それらをつなぐ非駆動の屈曲軸をクローラの 推進力のみで受動制御し，単純な構造でマルチクローラのような高い階段踏破性を得た。

マルチクローラは米国の'ANDROS' (5)などで古くからその効果が知られ，'UMRS-2009'(6), 'Aladdin'(7), 'Kenaf'(8)では，瓦礫等のランダムな不整地を踏破するため，本体クローラの前後に左右一対の起倒可動式サ ブクローラ (フリッパ) を備えており（6クローラ），左右のアプローチ角を独自に違う角度にもできる．ま た, 'KOHGA $2^{\prime(9)}$ では起倒可動式の独立 4 クローラ構造で同様な能力を有している. 一方，本ロボットでは 2 章(1)項の通り，専ら階段等の人工直交系平面構造物が対象なので，本体中心線上のただ一つの起倒可動式サ ブクローラ (フリッパ) でシンプルに対応した. 


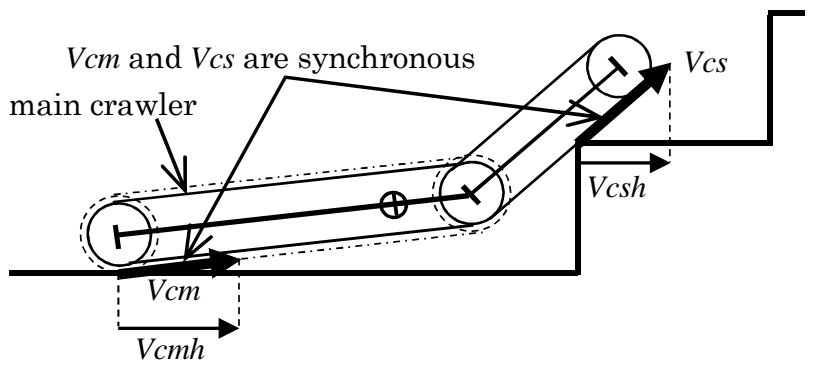

The ratio between velocity of $V c m$ and $V c s$ are fixed and synchronous (In most case, $V c m=V c s$ ).

However, the ratio between $V c m h$ and $V c s h$ those varies according to the angle between Vcm and Vcs. So the ratio between $V c m$ and $V c s$ should be passively changeable, otherwise either crawler slips.

Fig.3 Relation between the velocity of main crawler and and sub crawler when sub crawler is synchronous driven.

その一つのフリッパの接地のみを制御, 確認するため, 操縦が容易となった.

また，本体中心線上にあることでフリッパとマニピュレータとの兼用ができ，システム構造の一層の単純 化を図ることができた．尚，文献(3)〜(8)の事例ではサブクローラ（本体にある左右クローラの前あるいは後 の起倒式のもの）の回転はメインクローラと同期した駆動式である（文献(4)の事例でも左右独立に前後のク ローラ間の回転は同期している). しかし，メインクローラとサブクローラの階段への接触角度等が異なると， 車体の推進に合わせて両者の動きが相互干渉して内力で滑りを生じることがある（図 3).

一方，本ロボットではサブクローラの回転を非駆動とし，接触した対象に従動する（パッシブ）方式を取 っており，そのような不具合は生じない. 'Helios-VII'(10)では左右 2 クローラと，本ロボットと似た中心線上 のマニピュレータを備えるが，ランダム不整地踏破のために左右クローラが独立にスイングできるようにな っており，マニピュレータを使って先端のホイールを接地させてクローラと協調動作させ，急傾斜の登坂を 可能としている。 ホイールは従動式（パッシブ）で，本ロボットと同様，図 3 の問題を解決している.

（2）オペレータは，ロボット自体を直接見られないので，遠隔操縦で長い階段を登降坂させる際，階段の進行方 向に沿って直進させるのは難しく，ロボットが斜めに進むと，階段のエッジへのクローララグの食付きが不 完全になる，あるいは，ロボットが階段の端に接触するなど，不都合である。階段に沿って登降坂させよう とする場合, ロボットの進行方向が傾いた際は，傾斜センサの出力から，高く上がった側のクローラを減速 して傾きを自動的に修正する直進登降坂支援機能を盛り込んだ（図 4)。その制御アルゴリズムを以下，およ び図 5 に示す.

図 4 のような階段の登降坂角（最大傾斜線方向角）を $D$ （登坂時 $D>0$ ）, 階段の直進方向に向かっての傾 き方向角を $S$ （登降坂時とも進行方向に向かって右に傾いた際， $S>0 ）$ とすると, 傾斜センサの出力 $F$ は,

$$
F=\sin S \times D
$$

に比例する. その出力を用い，傾き方向角 $S$ の絶対值を減らすように，高く上がった側のクローラの速度 指令值を減ずる. 尚, 安全性を高めるため, 沈んだ側のクローラの速度指令值の増加は行っていない. 左右 のクローラ速度指令值（オペレータからの指令值）をそれぞれ $v r ， v l$, 直進登降坂支援機能による左右クロー ラの修正速度指令值をそれぞれ $V R, V L ，$ 修正係数を $k d$ とすると，

$$
\begin{aligned}
& V R= \begin{cases}v r & (S \geqq 0) \\
v r-k d \times F=v r-k d \times \sin S \times D & (S<0)\end{cases} \\
& V L= \begin{cases}v l-k d \times F=v l-k d \times \sin S \times D & (S \geqq 0) \\
v l & (S<0)\end{cases}
\end{aligned}
$$

となる，尚，さらに，修正值を速度に応じて加減することも考えたが，実施していない。 


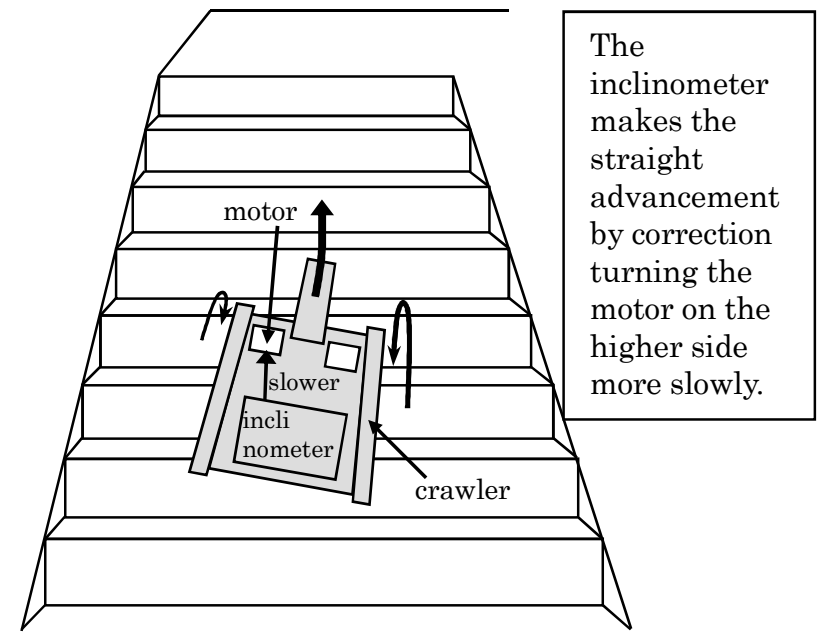

Fig.4 Straight ascending and descending assist system

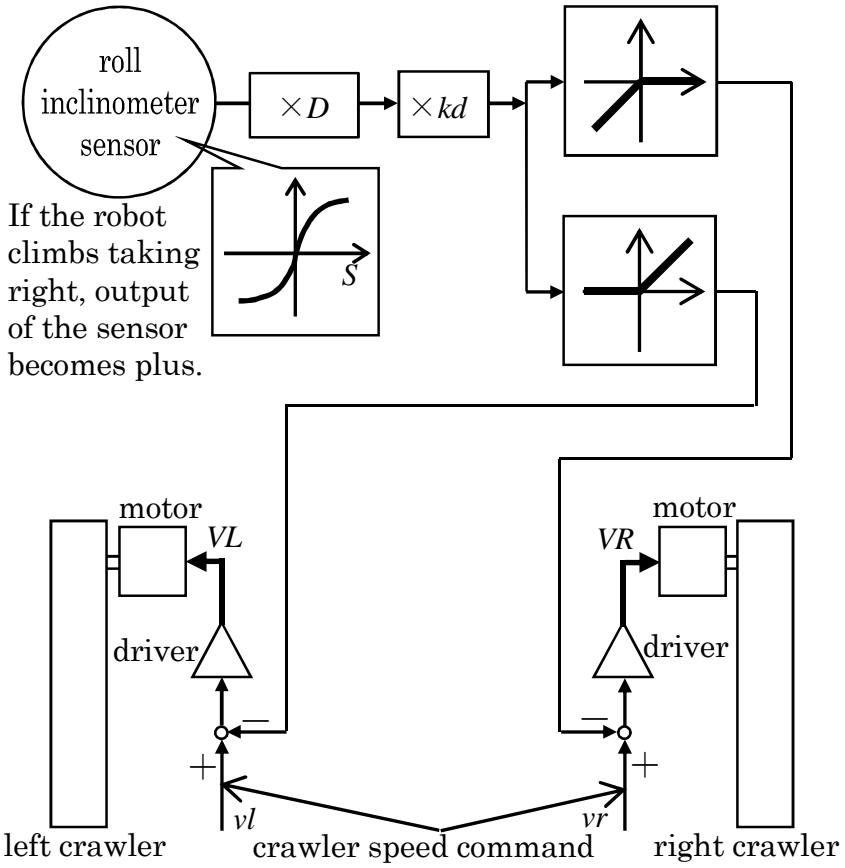

Fig.5 Algorithm of the straight ascending and descending assist system

後述する $7 \cdot 2 \cdot 1$ 項の階段において, 直進登降坂支援機能は有効に機能し, 左クローラを全速, 右クロー ラをほぼ半速度指令值（オペレータからの指令值）で登坂させた場合, 本機能なしでは $7 \cdot 2 \cdot 1$ 項の階段で 中央真っ直ぐに置いたロボットが，斜面方向距離に $1 \mathrm{~m}$ 弱進んで階段右端に当たったが，本機能により 1 階 分の高さ約 $3.5 \mathrm{~m}$ の階段（斜面方向長さは約 $6 \mathrm{~m}$ ）を端に接触せずに登り切ることができた。通常はあり得な い操作であるが，煙などで前方視界が不十分な場合などに有効な機能であることを確認した。

尚, 文献(6)の事例では，似た機能として，車体ヨ一角の光ファイバジャイロにより，直進した際のヨー角 を基準として，進行方向がずれた場合，本ロボットと同様に（図 4)，ずれて進行が進んだ側のクローラ速度 を抑制して車体方向を修正し，登降坂の操作性を向上させている.

（3）操縦のためのカメラは図 6 のように車体前端に備えると，障害物は大きく近接的に見えるが，ロボット自体 との位置関係が把握しにくい，一方，図 7 のように，車体後方高所に備え，障害物とともに車体前端を含め て俯瞰すると，車体前端に対する障害物の位置関係が明確になり，一般的に操縦性が向上する. 実際は, 図 6 と図 7 の両方を合わせた 2 台のカメラ画像を利用した。また，音響のモニタ機能も現場の臨場感を得るには 有用であり，備えた。
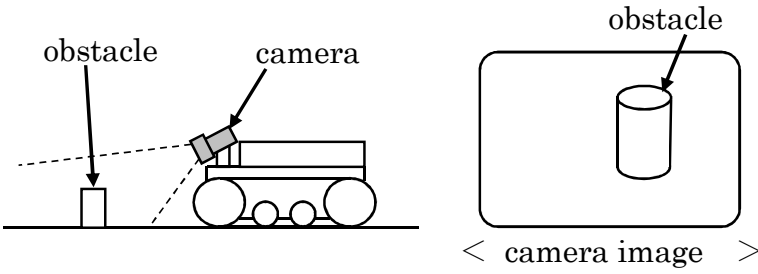

Fig.6 The position of the front camera for driving
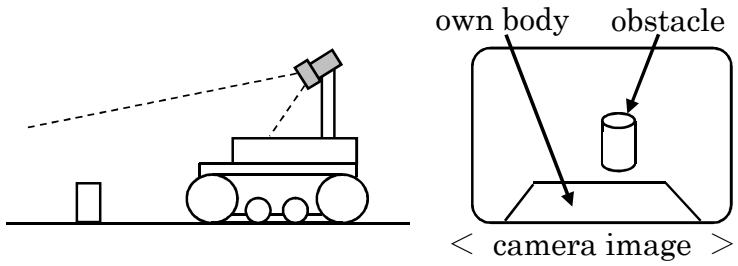

Fig.7 The position of the rear camera for driving

（4） 1 人で運ぶことができる．具体的には手で運ぶことができるか，背負って運ぶことができる．本体総質量約 $25 \mathrm{~kg}$ 以下とし (一般に人に持上げさせてよいとされる最大質量の目安は $25 \mathrm{~kg}$ とされている), 寄り付きが難 しい現場付近に迅速に搬入，展開できる. 
（5）（1）で記した，サブクローラ（フリッパ）をアームの一部として兼ねた小型マニピュレータを備え，先端の ハンドで軽作業（危険物除去，サンプリング等）ができる(11). また，マニピュレータ先端部にもカメラを備 えた．マニピュレータを可動式雲台として扱うことで，カメラを対象物に柕き込ませることができる.

尚，図 9 の本体側面図に示寸ように，本マニピュレータの前後（起伏）等姿勢変化により，重心位置の前 後ができる.サブクローラ（フリッパ）が接地（一直線）の状態で，マニピュレータのみによる水平重心移 動距離は約 $\pm 25 \mathrm{~mm}$ である．階段，段差の登りでは，自重を支持するエッジ位置に対して，重心位置を前方 （上方）に，降りでは，後方（上方）に移動することで，傾斜面上で，重心安定性を増加できる（図 8 のb.）.

（6）無線遠隔操縦式とする. 電波法下で実用的な距離で信号伝送, 画像伝送とも行うため, 市販の SS（スペク トラム拡散式) 無線機を使用する. 操縦信号, 車体モニタ信号, そしてカメラ動画像を多重化して授受する.

（7）動力源には充電式電池を使用し, 通常の建物の 1 階から 3 階程度以上の距離（十分に危険場所から離れた とみなせる）を電線なしで往復移動でき，その間の移動，到着目的地での適切な時間（最大 1 時間程度）の マニピュレータ操作，視察画像伝送などができる.

（8）探查作業として，危険物が仕掛けられた自動車等の床下に入り(5)項のマニピュレータ先端のカメラで走査 ができる．そのために車体高を低くした．結果的に重心を低くでき，(1)で述べたように急傾斜登降坂が安定 して行える.

\section{4. 駆 動 系 の 設 計}

\section{$4 \cdot 1$ 走行系各部寸法の設定, 検証と問題}

\section{$4 \cdot 1 \cdot 1$ 登降坂を行う階段の想定}

ロボットを登降坂させる階段, 踊り場について, 建築基準法における階段の段の最大規定寸法は, 踏面 (一段 の奥行き) で小学校等の $260 \mathrm{~mm}$ 以上，蹴上げ（一段の高さ）で家庭用の $230 \mathrm{~mm}$ 以下である. 本ロボットの運用 を想定する一般的な公的な場では踏面 $300 \mathrm{~mm}$ ，蹴上げ $200 \mathrm{~mm}$ 等が多い.

後述の $7 \cdot 2 \cdot 1$ 項の試験（図 13）ではそれぞれ $290 \mathrm{~mm} ， 200 \mathrm{~mm}$ であった（傾斜角 $34.6 \mathrm{deg}$ ）。また，階段幅 は建築基準法から最小 $750 \mathrm{~mm}$ を想定した。

\section{$4 \cdot 1 \cdot 2$ 必要な接地長の決定}

さらに, 踏面 $300 \mathrm{~mm}$, 蹴上げ $220 \mathrm{~mm}$ の厳しめの階段（傾斜角 $36.3 \mathrm{deg}$ ）を想定した．安定に登り降りするた めには，図 8 のように登坂中は重心の後方下方（図 8 の図上では重心位置の左下方）のクローラ部が必ず 1 つ以 上の階段エッジに載り，荷重支持されていなければならない，そのためには，本ロボットの場合，サブクローラ とメインクローラを合わせた直線状でのクローラ総接地長が $900 \mathrm{~mm}$ あれば十分であることを図より求めた.

\section{$4 \cdot 1 \cdot 3$ 各主要寸法の決定}

階段幅 $750 \mathrm{~mm}$ の制約から車体幅は $500 \mathrm{~mm}$ とした。 これと踊り場の踏面の関係から車体長は $700 \mathrm{~mm}$ とした. $4 \cdot 1 \cdot 2$ の接地長 $900 \mathrm{~mm}$ を満足するために，メインクローラ接地長 $580 \mathrm{~mm}$, サブクローラ接地長 $320 \mathrm{~mm}$ と した.サブクローラ (フリッパ) 水平時, $900 \mathrm{~mm}$ の一直線の接地長が得られる. 尚, サブクローラは 3 章(1)項に 示寸通り従動式で非駆動なのでメインクローラにはあるラグは不要であり，備えていない.

\section{$4 \cdot 1 \cdot 4 \quad$ ピッチずれによる脱落衝撃発生の問題}

メインクローラが 2 ケ所以上の階段エッジに接している図 8 のいずれの場合においても，メインクローラの荷 重支持は，任意のピッチの階段では，その斜面方向エッジ間距離と，ラグのピッチ $(30 \mathrm{~mm})$ の整数倍長が一致し ない限り, 一カ所で行われている. そのためラグには十分な強度を与えている. そして, 図 8 の. で, エッジ B の部位かその上に位置するエッジのうち, エッジ B が荷重支持を行っていた場合, 上記の不一致があることで, d. 几移行時に荷重支持ラグの切り替わりが起こり, ラグ 1 ピッチ長以内の脱落が生じ, 衝撃が発生する. しかし実 機では後述の $7 \cdot 2 \cdot 1$ 項の試験時には問題とはならなかった. 最悪のケースとして, 約 $35 \mathrm{deg}$ の登坂角度で ラグのピッチ 1 つ分脱落を生じさせて衝撃を発生させても，実験ではラグが破損する，あるいは，ロボットが滑 
り落ちるなどのことはなかった.

但し，このような不連続な荷重支持でも滑らかに脱落なく駆動系への衝撃を抑えて登降坂できるようにするこ とは重要な課題である. 文献(6)の事例では，そのような脱落などの際の駆動系への衝撃で駆動機構を損傷させな い動力伝達装置を採用している. また, 文献(9)の事例では上記脱落への対応として, クローラの材質を軟質なゴ ムにした上でラグピッチを密にすることにより，脱落の発生，衝撃を抑えている.

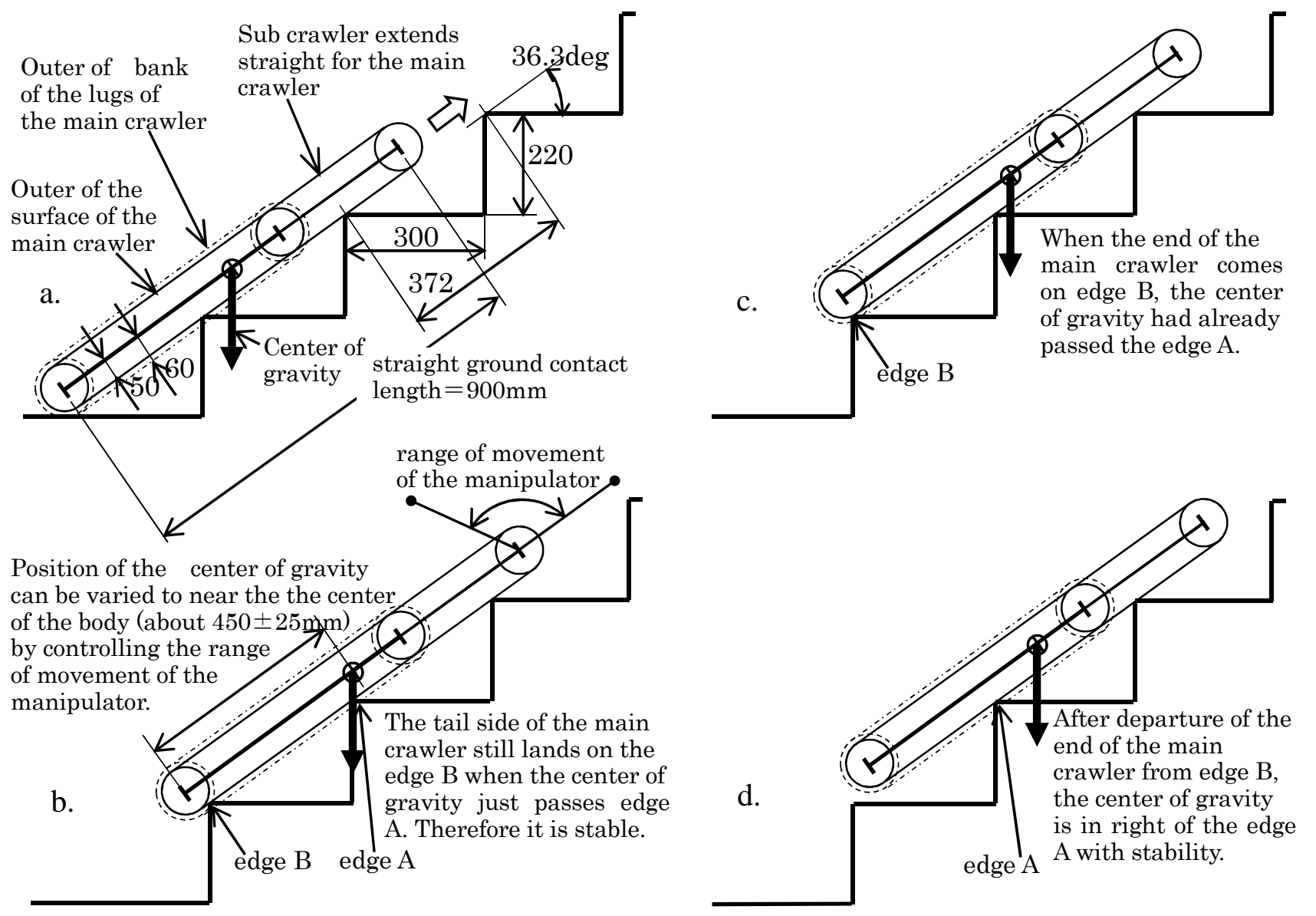

This is a sample of ascending the stairs of severe condition. It's necessary that the crawler is always supported at one place or more by the edge of the stairs in the left of center of gravity, in this sample. Therefore, it is possible to ascend the slope with stability. It is also possible to descend similarly with stability because center of gravity is at about the center of the maximum ground contact length $900 \mathrm{~mm}$.

Fig.8 Sequence of the ascending steep stairs

\section{$4 \cdot 2$ 走行系}

\section{$4 \cdot 2 \cdot 1$ 設計目標}

走行系は通常の滑らかな床面, そして $4 \cdot 1 \cdot 1$ 項で述べたような $40 \mathrm{deg}$ 弱の階段・斜面を登降坂でき, さらに 一般に最大の駆動力が必要とされる摩擦係数の高いコンクリート，アスファルト舗装路面上での超信地旋回がで きるように設計した．実際には，40deg 以上を登坂して斜面方向に最高速度 $0.3 \mathrm{~m} / \mathrm{s}$ で走行できることとした。 最大総質量 $30 \mathrm{~kg}$ で推進力 $F_{S}$ は, 直進時左右クローラ各々で,

$$
F_{S} \geqq(30[\mathrm{~kg}] \times 9.8[\mathrm{~m} / \mathrm{s} 2] \times \sin (40[\mathrm{deg}])) / 2=94.5[\mathrm{~N}]
$$

左右各 crawler の必要駆動出力 $W_{S}$ は,

$$
W_{S} \geqq(94.5[\mathrm{~N}] \times 0.30[\mathrm{~m} / \mathrm{s}])=28.4[\mathrm{~W}]
$$




\section{$4 \cdot 2 \cdot 2$ 走行系モータの選定}

$4 \cdot 2 \cdot 1$ 項で求めた駆動力 $W_{S}$ と, 超信地旋回駆動をともに満足するパワーから, 各クローラの必要出力は機械 系効率（最悪 $30 \%$ 程度）も考慮して, 約 $100 \mathrm{~W}$ 以上が必要と試算した。階段・斜面登降坂時の停止時に自質量を 停止保持できるための負作動ブレーキを備えた maxon motor ${ }^{(12)}$ の定格出力 $250 \mathrm{~W}$ 品を，左右クローラに 1 個ずつ 装備した. 減速器は遊星型とし, 減速比は 100 を採用した。 モータ形状, 専用ブレーキユニットや専用小型減速 器等のオプションの有無により選定が制約されたため, モータ出力は大きめとなったが, 結果的に最高速度, 最 高駆動力とも十分となった.

水平最高直進速度は $0.5 \mathrm{~m} / \mathrm{s}$ を目標としたが，無制御ではその倍の $1 \mathrm{~m} / \mathrm{s}$ 程度となった。階段登降坂では，操作 ミスでの急峻な動きによる脱落を防ぐため，登降坂角約 $10 \mathrm{deg}$ 以上では最高速度約 $0.4 \mathrm{~m} / \mathrm{s}$, 約 $35 \mathrm{deg}$ では最高速 度約 $0.2 \mathrm{~m} / \mathrm{s}$ に制限した．但し実験では $4 \cdot 1 ・ 4$ 項に記した荷重支持しているラグの切り替りによる小脱落に対す る安全策として, 登坂で約 $0.25 \mathrm{~m} / \mathrm{s}$, 降坂では約 $0.15 \mathrm{~m} / \mathrm{s}$ 以上で進ませなかった. 尚, それら值は限界值ではなく, 試験による経験的なものである.

\section{$4 \cdot 3$ サブクローラ（フリッパ），マニピュレータ系駆動モータの選定}

サブクローラは 3 章(1)項の通り, 従動式なので駆動モータはない. そして, マニピュレータのアームフレーム を兼㸚るサブクローラ(フリッパ)の起倒には負作動ブレーキ付きの maxon motor の $120 \mathrm{~W}$ 品を装備した. また, その先のひじユニットの起倒には同社製負作動ブレーキ付きの $50 \mathrm{~W}$ 品を装備した．その他ハンドユニット用には 手首の起倒用とその回転用に 2 個の $5 \mathrm{~W}$ モータを差動で用い，グリッパの開閉・把持用には $20 \mathrm{~W}$ 品を装備した.

尚, $4 \cdot 2 \cdot 2$ 項の走行系同様, オプションに拘束され, 出力過大なモータが選定されたが，支障はなかった.

\section{5. 機 構 の 設 計}

以上をまとめた本ロボットの基本諸元を表 1 に示寸. 図 9 に構造 2 面図を示す。サブクローラ（フリッパ）を 兼㸚たマニピュレータアーム部先端にひじフレームが取り付けられ，さらにその先にピッチ／ロールできる手首 を備えたグリッパが装備されている．グリッパは約 $1 \mathrm{~kg}$ の物体を扱うことができる．ボディはアルミモノコック で，尾部の着脱式ペイロードボックスには，試験時は車体内と同容量の増加電池を搭載した。

Table 1 Principal spec of the robot

\begin{tabular}{|l|l|l|}
\hline \multicolumn{2}{|l|}{ Total weight } & $28.8 \mathrm{~kg}$ \\
\hline Outline measurement & see Fig.9 \\
\hline Max. speed & on flat floor & $0.5 \mathrm{~m} / \mathrm{s} \quad(1.8 \mathrm{~km} / \mathrm{h})$ \\
\hline & on 35 degree & $0.2 \mathrm{~m} / \mathrm{s}$ \\
\hline
\end{tabular}

\begin{tabular}{|l|l|}
\hline Max. climbable slope & more than 35 deg \\
\hline Min radius of turning outer & $0.86 \mathrm{~m}$ (by pivot turn) \\
\hline Max. payload of gripper & about 1.0kg \\
\hline Power supply & $24 \mathrm{~V} / 10 \mathrm{Ah} \mathrm{Ni-MH}$ \\
\hline
\end{tabular}

\section{6. 制 御 系}

システム構成を図 10 に示す. 本システムは見通しのきかない遠方（電波経路長で $100 \mathrm{~m}$ 程度）にロボット本体 を移動させ，その目的地や移動途中でカメラにより視察・監視を行い，目的地ではマニピュレータで小危険物， 毒物等の除去作業を行うことができる，そのため，ロボットは，固定地上局から無線伝送により，画像・音響を 確認しながら, 無線遠隔操縦される. ロボット本体の状態 (走行速度, 姿勢, 電池残量等), マニピュレータの形 状等をリアルタイムに操作コンピュータの状態モニタディスプレイ上で確認できる. 周囲環境（温度，ガス等） のセンサ類を尾部の着脱式ペイロードボックスに備えることもできる.

無線は，画像，制御伝送とも屋内利用を主とすること，また一般使用可能な市販品を使い易いことから，ギガ ヘルツ帯のものを使用した。ロボット上のカメラはモノラル音響も同時伝送でき，モーションjpeg 形式で圧縮し た動画像を無線伝送し，基地局側チューナで展開し，モニタディスプレイに送る．フレームレートは約 $15 \mathrm{fps，そ}$ してこのような場合, フレームレートより操縦感覚に影響が大きい伝送遅れは約 $0.5[\mathrm{~s}]$ であり, 低速の本ロボット では問題とならなかった。 


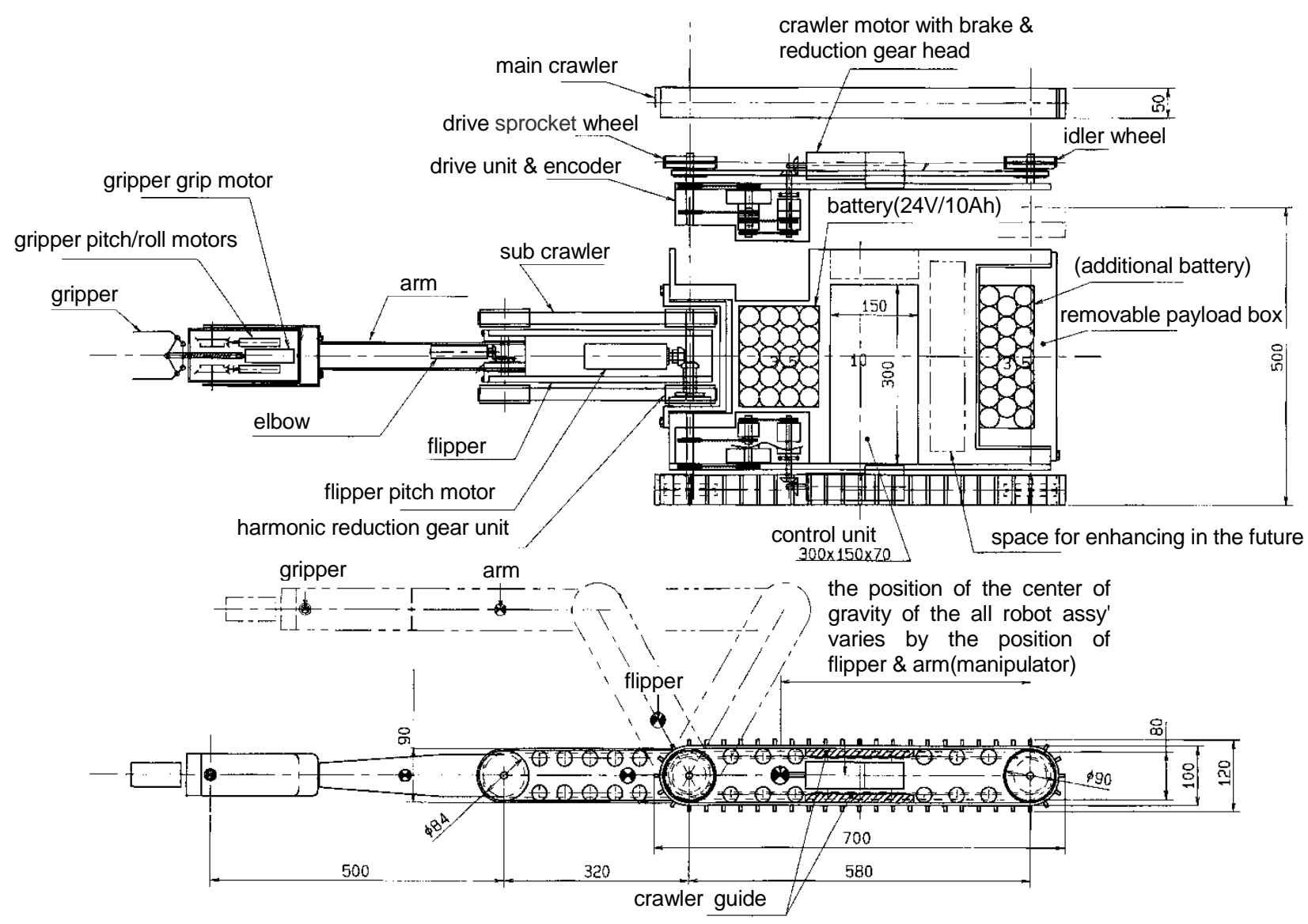

Fig.9 Drawing of internal structure of the robot

ロボット側では"TITech Wire'(13)を使用し，本体 CPUにも同シリーズの CPU ボードを使用した.

ロボット内部の I/O には'TITech Wire'LAN 接続用の D/A 出力ボード， A/D 入力ボード，DIO 入出力ボード， そしてエンコーダカウンタボードが装着されている. 左右クローラ走行モータにはエンコーダが装着されており， 操縦側の速度指令をデジタル的に速度制御（コンティニュアスパス制御(14)）しており, 停止時のドリフト微動等 が無い、サブクローラ（フリッパ）の起倒にも同様のモータが装着されているが，その起倒角度を知るためにエ ンコーダでなくポテンショメータが装備され，A/D を介して入力している.

走行，フリッパのモータ電流負荷はモータドライバを介してアナログモニタされており， サブクローラ（フリ ッパ）を倒して床や階段のエッジに接触して荷重が大きくなると，そのことは接触情報として操作コンピュータ の状態モニタディスプレイで操縦者に知らされる.

階段登降坂における，フリッパ動作シーケンスについては，それを半自動で行う従動制御モードと，その詳細 をオペレータが手動で行う手動モードがある. 図 1 でa.の状態で従動制御モードにすると, サブクローラを予め パラメータセットされている角度で持ち上げる（一般の階段ではメインクローラに対し上向きに約 40〜 $45 \mathrm{deg} に$ セットしていた)，そのままで直進させ，階段の第 1 段目を登って，車体のピッチ方向の傾きが概数階段の斜度 (一 般の階段ではやや少なめの約 $25 \mathrm{deg}$ に設定していた）を超えると，図 1 の c.のように自動的にサブクローラ（フ リッパ）をメインクローラに対して直線となるように固定する. 階段を登り切り，オペレータが図 2 の a.の状態 のタイミングを押しボタンで指示すると，フリッパは，浮いた状態から図 2 の b.のように，一定小トルク值とな るまで押下げられ, 踊り場の床に接触する. 一定小トルク值は実験では手動で調整したが, $5 \mathrm{~N} ・ \mathrm{~m}$ 程度が最適で あった. そしてさらに進んで, 図 2 の c.の倒れ込みが起こると, フリッパは急速に水平になる方向に押し動かさ れる. これに対し, フリッパは発生される小トルクに対して外力による角度変化が起きると, その角速度に比例 した抗力が発生するように制御されている. それにより, 倒れ込みの衝撃が抑えられ, 軟着地が行われる. 簡単 な半自動アシスト機能であるが, 効果的であった. 


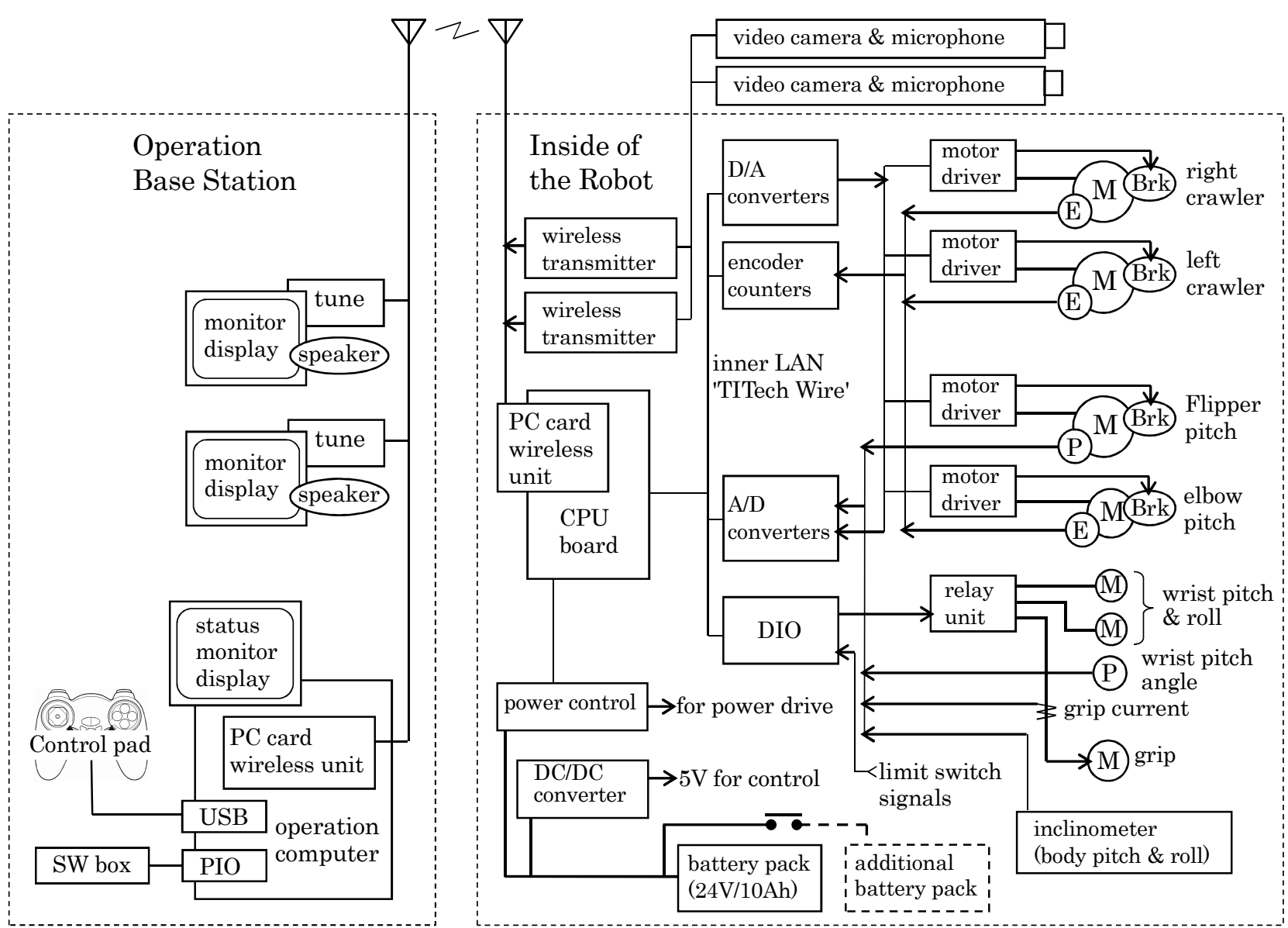

Fig.10 System Configuration

この操縦支援機能は 3 章(2)項に記した階段登降坂での直進登降坂支援機能と共に, 本ロボットシステムの主要 機能であり, 階段登降坂の操縦性が大きく向上した.

そして, 本ロボットの操縦モードには, 上記の直進登降坂支援機能の $\mathrm{ON} / \mathrm{OFF}$, フリッパの従動制御モード ／手動制御モードの切り替えがある（両者は独立した機能で，階段登降坂時他で併用できる）.

具体的な操縦は, 市販の PC ゲーム用操作パッドに取り付けられている指先操作ジョイスティック, スイッチ, および，別置きのスイッチボックスにより行う．

スイッチボックスでは, 上記モードの設定, 表示の切り替え等を行う. PC ゲーム用操作パッドの左右ジョイス ティックでは左右クローラ/マニピュレータ（カメラ雲台兼用）の操作を, そして PC ゲーム用操作パッドのスイ ッチでは, 左右ジョイスティックで操作する作動軸の割り当てや, 速度比の切り替え等を行う.

操縦支援機能として，本ロボットが有する半自動レベルより進んだ半自律レベルにある事例として，文献(7)の 事例では, 4 つのフリッパの接地情報や非接触距離センサでの対地距離情報により, 走破のためのフリッパ形状を, 半自律的制御則を定めて操緃支援し，不整地，階段等の走破性を高めている.

\section{7. 運用}

\section{$7 \cdot 1$ 全体構成}

\section{$7 \cdot 1 \cdot 1$ 外観}

本ロボットが平床上に転がっている手榴弾模型を除去しようとしている写真を図 11 に示す. ハンド上にカメラ が 1 台, 尾部のアンテナタワー上にもう 1 台のカメラが装着されている. 前者は図 6 の車体前端カメラに相当し, 後者は図 7 の後方カメラに相当し, 操縦を容易にしている. 尚, 階段降坂時は, マニピュレータを操作して, 八 ンド上カメラで，ロボット前下方等をのぞき込ませて，必要な視界を得ている. 


\section{$7 \cdot 1 \cdot 2$ 搬送について}

3 章(4)項を具体化して，本ロボットを市販の登山用しょい子を用いて移送しているところを図 12 に示す.

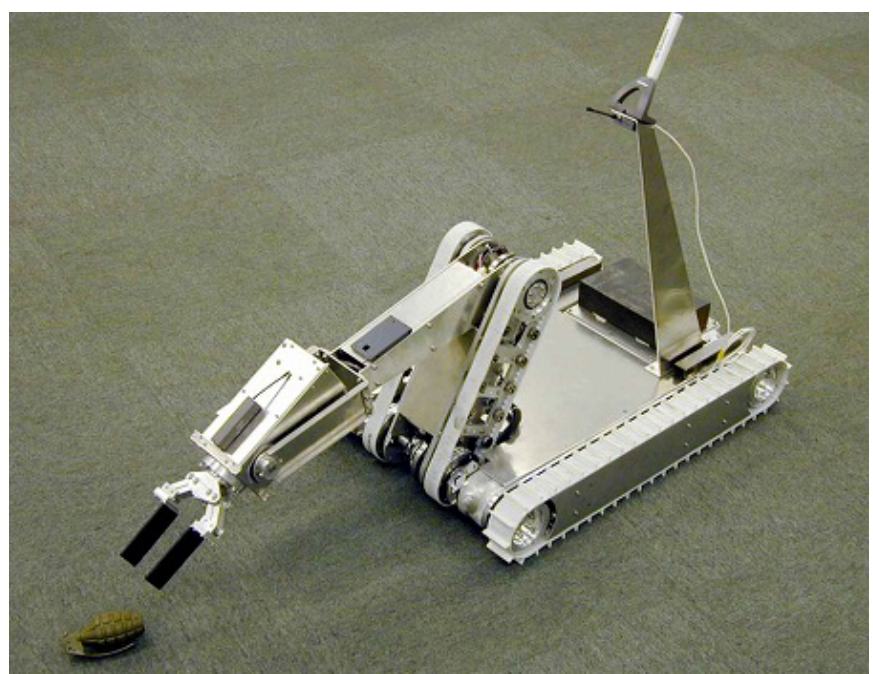

Fig.11 Scene to which robot uses manipulator and a model of grenade is being removed.

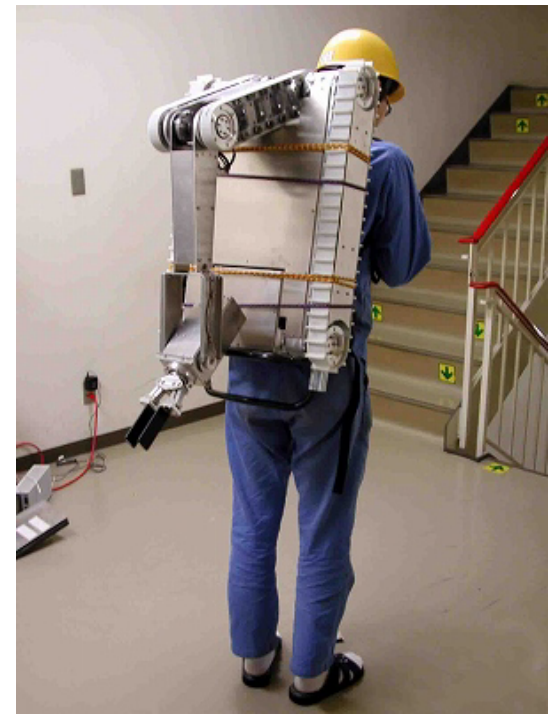

Fig.12 Scene that a person is shouldering the robot with the crimbing mountain transportation tool.

\section{$7 \cdot 2$ 運用試験}

\section{$7 \cdot 2 \cdot 1$ 階段登坂}

図 13 に, $4 \cdot 1 \cdot 1$ 項に記した一般的な階段 (踏面 $290 \mathrm{~mm}$, 蹴上げ $200 \mathrm{~mm}$, 有効幅約 $1,150 \mathrm{~mm}$, 傾斜角 $34.6 \mathrm{deg}$ ) を登坂している状況を示す. 3 章(1)項の図 1 , 図 2 の際のサブクローラ（フリッパ）の押し当て，停止は 6 章に 記した従動制御機能により行われ，3 章(2)項の直進登降坂支援機能と併せて階段登坂を行った.

尚，コンクリート表面の階段では難なく階段登坂ができたが，屋内に多いリノリウム床の場合，最初の段に

乗り上がろうとする際（図 1 のb.の状態での前進), メインクローラがポリウレタン樹脂の場合, その最下端の 接地面と床との間の摩擦係数が小さく(推定摩擦係数 : 約 0.2), 滑ってしまい登坂始めができなかった. サブクロ ーラ（フリッパ）が非駆動の従動式のため，駆動力が不足することでの欠点である．しかし，クローラをクロロ プレン系ゴム（硬度約 60, 推定摩擦係数 : 約 0.5）に換えることで，メインクローラ下端と床との摩擦が増大し, 円滑な登降坂ができるようになった。クロロプレン系ゴム製では接地摩擦が大きいため，コンクリート表面の階 段では踊り場などで旋回性が悪化することが懸念された。そのため，当初，接地摩擦が小さいポリウレタン製ク ローラを使用したが， $4 \cdot 2 \cdot 2$ 項の通り，ラインナップの制約で，大出力モータを採用したので問題なかった.

尚，図 6，図 7 のものともカメラは水平視野角 $100 \mathrm{deg}$ くらいのものが使いやすかった.

\section{$7 \cdot 2 \cdot 2$ 屋内視察}

図 13 のような形態で，1階から 3 階までの踊り場がある約 $35 \operatorname{deg}$ の傾斜の階段を 2 台の搭載カメラで（操縦者 はロボット本体を見られない)，3階の「現場」を視察し，状況を動画で伝えた．鉄筋コンクリート建物内の階段

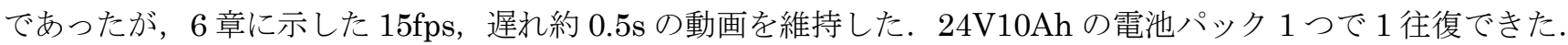

往復に要した時間は， 1 階から 3 階の平床に入って走行を開始する迄に約 $4 \mathrm{~min} 5 \mathrm{~s}$ (約 $245 \mathrm{~s}$ ), 往復で 1 階の 床に降りきる迄に約 $9 \min 10 \mathrm{~s}$ （約 550s） であった。降坂に，より多い $5 \min 5 \mathrm{~s}$ (約 $305 \mathrm{~s}$ )がかかったのは，降り る際の安全確認に，より慎重な操縦になったためと，階段と踊り場間を安定に移行するためのサブクローラ（フ リッパ）は，登坂で，より効果が大きかったためである。

尚，3 階の登坂を，高さ $8[\mathrm{~m}]$ とすると，効率 $100 \%$ での登坂エネルギ : Et は， 
$E t=30[\mathrm{~kg}] \times 9.8[\mathrm{~m} / \mathrm{s} 2] \times 8[\mathrm{~m}]=2,352[\mathrm{~J}]$

一方，搭載電池のエネルギは，70\%が使えるものと仮定して，

$$
E b=24[\mathrm{~V}] \times 10[\mathrm{~A}] \times 3,600[\mathrm{~s}] \times 0.7=604,800[\mathrm{~J}]
$$

実際は, 制御系の常時電力消費, 操縦のもたつきによる時間的効率 : 0.3 , 機構系効率 : 0.3 , 電力系効率 : 0.5 を全て考慮すれば，有効なエネルギ：Epは，

$$
E p=E b \times 0.3 \times 0.3 \times 0.5=27,216[\mathrm{~J}]
$$

程度と考えられる.

$$
E p>>E t
$$

であり，3 階迄しか試験していないが，10階以上の建物でも，十分往復してくることができる.

但し, 採用した SS 無線機は $2.4 \mathrm{GHz}$ 帯の微弱電波式であったが，見通しのきかない屋内階段で使用したので, 1 階から 3 階までの運用がやっとであり, 3 階より上に向かおうとすると通信不能に陥った.より低周波 $(400 \mathrm{MHz}$ 帯）ではあるが，特定小電力品（見通しで $1 \mathrm{~km}$ 以上到達とされる）などを使用することで，屋内でも到達距離が 伸びることが期待できるが，小型市販品が少なく，搭載面で難しい等の課題があり未実施である.

\section{$7 \cdot 2 \cdot 3$ 屋外視察}

図 14 に海外の警備等でよく行われる自動車床下を走査しようとしているところを示す.

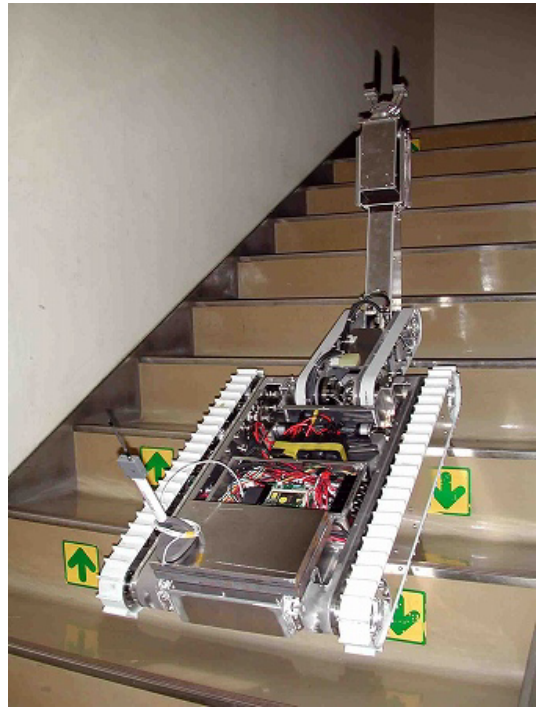

Fig.13 The robot is ascending the stairs of 34.6 degrees.

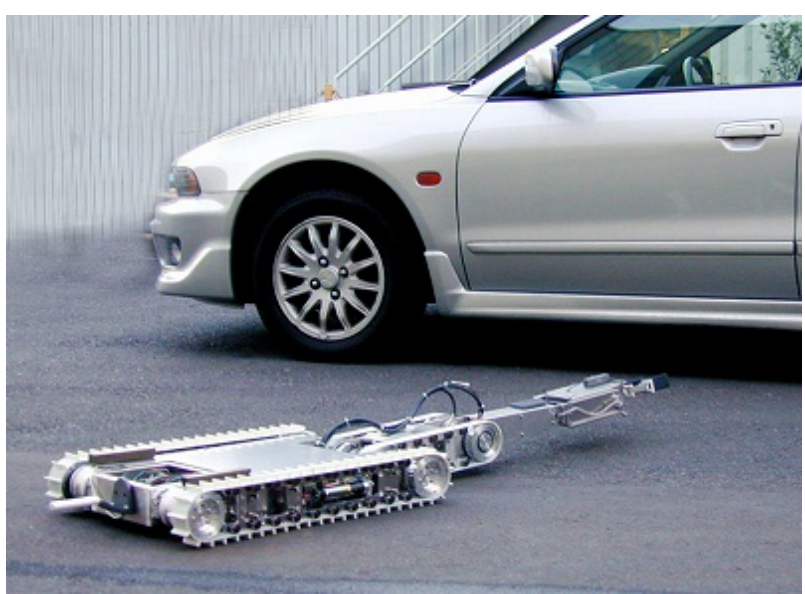

Fig.14 Scene to which robot makes the best use of thin body and bottom of car is scanned.

3 章(8)項の仕様で, 階段登坂を容易にするために, 車高, 重心を非常に低くしたことと併せて実現できた機能 である. 自動車等の床下に入り, 3 章(5)項のマニピュレータ先端に装備のカメラを上向きにしておき, クローラ を駆動して走査を行う. 当初, 走查操縦は難しかったが, ジョイスティックによるクローラ指令速度を高速・低 速で切り替えられるようにして（低速では速度を約 $1 / 15$ に細かくした），走査は効率的になった。

\section{8. まとめ}

複数のカメラや，サブクローラ（フリッパ）の接触検知情報などがあっても，ロボット本体の様子を直接見ら 
れない場所からの階段の登降坂操縦は難しい. $4 \cdot 1 \cdot 4$ 項のようなクローララグのピッチずれによるクローラ脱落, あるいは，3 章(2)項で触れたように， ロボットが階段に対して誤って斜めに進み, 階段へのクローララグの食付 きが不完全になることによるクローラ脱落が，登降坂にとって危険で，オペレータにとっては不安であった.

前者は $4 \cdot 1 \cdot 4$ 項のように, ロボットの滑り落ちを招くことはなく, 文献(9)の事例のようなクローラの改善に より解決できるが，本ロボットの操縦制御系開発では，専ら後者の解決が重要であった.

これに対しては 3 章(2)項の直進登降坂支援機能の開発，装備が非常に効果的であり，課題を解決できた.

階段は一般に非常に定式化された構造，寸法であり，直進登降坂支援機能，そして 6 章で記したフリッパの従 動制御（半自動制御）機能を組合わせ，加えて階段寸法計測機能を備え，階段登降坂自体をより高度に自動化さ せることが期待できる.

今後，そのような課題を解決し，本ロボットのようなシンプルな構造を維持しながら，使いやすいロボットの 実用化に努めて行きたい.

\section{文 献}

（1）妻木俊道, “危険作業ロボット”,日本ロボット学会誌, Vol.18,No.7(2000),pp.946-950.

(2) “xBot prepares to enter the field", unmanned VEHICLES, Vol.13,No.2(2008),pp.12-14.

(3) Brian Yamauchi, "Wayfarer: An Autonomous Navigation Payload for the PackBot", Proceedings of AUVSI Unmanned Vehicles North America(2005).

(4) W. Lee, S. Kang, M. Kim, and M, Park, "ROBHAZ-DT3 Teleoperated Mobile Platform with Passively Adaptive Double-Track for Hazardous Environment Applications“, Proceedings of IEEE/RSJ IROS, Vol.1(2004),pp.33-38.

(5) REMOTEC SYSTEMS \& TECHNOLOGIES, Remotec Westinghouse, 'ANDROS' series catalogue(1995).

(6) 大坪義一, 川邊慶久, 宇田宏, 小林滋, 小林泰弘, 山本祥弘, 梅田栄, 海藻敬之, 前田弘文, 高森年, 田所諭, “閉 鎖空間内探査移動ロボットのための操縌インタフェースの開発”, 日本機械学会ロボティクス・メカトロニクス講演 会講演論文集(2010), 1A1-C-04.

(7) Kazunori Ohno, Shouichi Morimura, Satoshi Tadokoro, Eiji Koyanagi and Tomoaki Yoshida, "Semi-autonomous Control of 6-DOF Crawler Robot Having Flippers for Getting Over Unknown-Steps", Proceedings of IEEE/RSJ IROS (2007), pp.2559-2560.

(8) 小柳栄次, “サブクローラを持つレスキューロボット”,日本ロボット学会誌,Vol.28,No.2(2010),pp.147-150.

(9) Hitoshi Miyanaka, Norihiko Wada, Tetsushi Kamegawa, Noritaka Sato,Shingo Tsukui, Hiroaki Igarashi and Fumitoshi Matsuno, "Development of an unit type robot KOHGA2 with stuck avoidance ability", IEEE International Conference on Robotics and Automation(2007), pp.3877-3882.

(10) M.Guarnieri, P.Debenest, T. Inoh, E. Fukushima, S. Hirose, "Mechanical design and basic tests on Helios VII a vehicle for search and rescue operations", Journal of Advanced Robotics. Special Issue on Rescue Robotics, Vol.19(2005), pp.901-927.

(11) 内田康之, “地上用携行多機能型ロボットの提案”, 第 21 回日本ロボット学会学術講演会予稿集(2003), 3G26.

(12) マクソンジャパン(株), maxon motor カタログ(2004).

(13) 福島 E. 文彦, 滝田謙介, 広瀬茂男, 中村亨, “知能ロボット用シリアルバス型制御システムの研究-TITech Wire の開 発”, 第 7 回ロボティクス・シンポジア予稿集(2002), pp.155-160.

(14) 妻木俊道, 小林洋司, 中野栄二, 内山研史, 玉田守, “急傾斜山林地用実大歩行ロボットの開発”, 日本ロボット学 会誌,Vol.27, No.4(2009),pp.102-112. 